\title{
EFEITOS DAS PROMESSAS DE COMPRA E VENDA DE IMÓVEIS
}

\author{
Altino Portugal Soares Pereira \\ Professor da Faculdade de Direito da Universida- \\ de do Paraná
}

Pelo estudo da mais recente legislação, verificamos que dois efeitos primordiais decorrem das promessas de compra e venda de imóveis registradas, a saber: a) a constituição de um direito real e b) a possibilidade da execução compulsória, pela forma específica, dos contratos celebrados.

Quanto ao primeiro efeito, nenhuma dúvida pode restar, em face das disposições expressas do art. $5 .^{\circ}$ do Decreto-lei $n .^{\circ}$ 58, de 10 de dezembro de 1937 , e do art. $1 .^{\circ}$ da Lei n..$^{\circ} 649$, de 11 de março de 1949. Declarando o primeiro dêstes que o direito real oponível a terceiros é quanto à alienação ou oneração posterior, cria, iniludívelmente, para o promitente comprador, cuja promessa está registrada, uma situação equivalente à dos demais titulares de direitos reais, para o exercício dos direitos respectivos, que também se afirma erga omnes.

Sejam quais forem as denominações propostas para o direito decorrente da promessa de compra e venda registrada, seja qual for a feição que se lhe reconheça, não se lhe pode negar o que a própria lei lhe conferiu: o título de direito real. $\mathrm{E}$ não se justificam as distinções que alguns juristas quiseram estabelecer entre o direito real oponível a terceiros de que trata $o$ art. $5 .^{\circ}$, do Decreto-lei $n .^{\circ} 58$ referido, e os demais direitos reais, pois, é óbvio que nem êstes seriam reais se oponíveis não 
fôssem a terceiros. É justamente a propriedade de se afirmar erga omnes um dos traços característicos dos direitos reais, em geral.

O segundo efeito, que consiste na possibilidade de execução, em forma específica, das promesisas registradas, também é declarado, expressamente, nos diplomas legais, acima citados (art. 16 do Decreto-lei n. ${ }^{\circ} 58$ mencionado e art. $1 .^{\circ}$, da Lei n. ${ }^{\circ} 649 \mid 49$, que dá nova redação ao art. 22 , do mesmo decreto-lei n. ${ }^{\circ}$ 58, e art. 346, do Código de Processo Civii, em vigor), que prevêem, quer a forma voluntária, quer a compulsória de execução. Alem de poder o promitente vendedor outorgar a competente escritura ao promitente comprador, ná ocasião própria, independentemente de qualquer chamamento, ainda por via dêste poderá evitar que se dê a execução compulsãria. Esta, é óbvio, virá como recurso extremo. E dar-se-à pela forma específica sempre que o respectivo contrato tcnha sido levado a registro e assegurará apenas o pagamento de perdas e danos, nos demais casos.

Em que pesem opiniões de autoridades respeitáveis, no sentido de que a execução in natura não depende do registro das promessas celəbradas (1), parece indiscutível que a última disposição legal a respeito (art. $10^{\circ}$ da Lei $n .^{\circ} 649 \mid 49$ ) veio reafirmar o pensamento contido no Decreto-lei n. $.^{\circ} 58 \mid 37$ e no Decreto $n .^{\circ} 3.079 \mid 38$. Quanto a êste regulamento, convém ressaltar o teor de seu art. 23:

"Nenhuma açá́o ou defesa se admitirá, fundada nos dispositivos dêste decreto $e$ do decreto-Lei $n .^{\circ} 58$, sem apresentação de documento comprobatôrio do registro "por êles instituido".

É imperdoável o exagêro dêste dispositivo que afirma a inviabilidade a qualquer ação. $O$ que se deve entender, em face de nossa legislação vigente, é que a execução em forma específica só se verificará, quando o respectivo contrato de pro-

1) Revista Forense, vol. CXXI, pág. 455, Revista Forense, vol. CXXX, pág. 89. 
messa de compra e venda de imóveis tiver sido registrado. Boa ou má, essa é a diretriz a seguir porque está em lei.

As nossas disposições legais atinentes à espécie inspiraram-se na necessidade inadiável de abroquelar os interêsses daqueles que, sem a menor segurança, investiam suas economias na aquisição de imóveis (2). E a maior garantia que se lhes podia dar, era a obrigatoriedade do registro das promessas, para a obtenção de seus principais efeitos. Todavia, como já dissemos, se o verdadeiro intuito do legislador foi proteger a pequena economia, hoje sobram razões para que o benefício concedido aos pequenos se estenda a todos os membros da coletividade a fim de que a sociedade viva em base estáveis e progrida.

Afirmando que a inserção, em lei, da exigência do registro das promessas de venda, é requisito essencial para sua execução, pela forma específica, não excluimos a possibilidade dessa forma de execução, em outros casos, em lei previstos, cuja natureza da prestação o admite de modo irretorquível, como é o do art. 863 do Código Civil.

A execução compulsória dar-se-à quando se verificar o inadimplemento da obrigação assumida pelo promitente vendedor, de outorgar a respectiva escritura de venda. Será in specie, mediante a adjudicação judicial do imóvel prometido ao comprador, ou, simplesmente compulsória, para o efeito de reconhecer a êste o direito ao recebimento da importância correspondente a perdas e danos o que, aliás, ocorre, frequentemente, nas chamadas promessas comuns de compra e venda.

Inúmeros outros efeitos aqui se poderão referir, além dos dois principais, acima nomeados. Queremos aludir aos efeitos das promessas relativamente à perda ou deterioração da coisa prometida, à percepção dos seus frutos e ao direito às benfeitorias na mesma realizadas.

2) Exposição de Motivos do M.॰ Francisco Campos, in "Comentários ao Código de Processo Civil, vol. IV, pág. 473, Luiz Machado Guimarães 
Convém salientar estas conseqüencias visto que a promessa de compra e venda é, hoje, um dos meios pelos quais se adquire a posse dos imóveis. Não raro, por meio dela se ajusta que o promitente comprador ficará, desde logo, investido na posse da coisa prometida à venda. Há, realmente, uma tradição, a título precário, ou seja, dependente de ratificação, porque, mesmo que a promessa se qualifique como irrevogável ou irretratavel, não deixa, por isso, de estar sujeita à rescisão, para o que é suficiente o inadimplemento de obrigações de qualquer das partes.

De tal modo, se houver a entrega da propriedade prometida, deverão aplicar-se aos casos ocorrentes as regras disciplinadoras da posse, para a fiel apuração das responsabilidades e justa conferência de direitos que às partes contratantes competirem.

No período compreendido entre a data em que foi realizada a promessa de compra e venda e a da celebração do contrato definitivo, muitas ocorrências poderão verificar-se, exigindo, de tal arte, pronta solução. Pode suceder, mesmo, que o contrato definitivo, por qualquer circunstância, não chegue a ser celebrado. 0 promitente comprador, contudo, pode não se ter, ainda, despojado da posse do imóvel que lhe foi prometido à venda, cuja entrega lhe foi feita. Eis porque não é menos interessante indagar-se qual a sua responsabilidade no caso de perda ou deterioração da coisa e quais os seus direitos e obrigações relativamente aos frutos produzidos, nesse periodo, e às benfeitorias no mesmo realizadas.

Parece irrecusável a conclusão de que tais hipóteses se regem pelo disposto no Código Civil, em vigor, arts. 510 a 519, atendidas, é claro, as peculiaridades do instituto. De tal modo, o promitente comprador será classificado, ou como possuidor de boa fé, ou como possuidor de má fé. Verificar-se-à a primeira hipótese, enquanto sua posse corresponder ao exercício normal do direito decorrente do contrato celebrado, ou quando isto já não suceda, enquanto o promitente vendedor não reclamar a restituição da coisa possuida. Ocorrerá a segunda, quando, existindo a necessária reclamação, formulada pelos 
meios competentes e fundada na lei e no contrato celebrado, se obstine, mesmo assim, o promitente comprador, em não se despojar da posse aludida.

O Egrégio Supremo Tribunal Federal decidiu:

"Não cumprida a promessa de venda pelo promissãrio-comprador, a sua permanência no imóvel prometido passa a constituir esbulho, passível de restituição possessória imediata" (Acórdão da 1a. turma, de 1.-10-1953, Rev. For., vol. 162, pág. 156).

Há, também, em relação ao caráter da posse (art. 491, do Código Civil) a possiblidade de sua transformação. Assim, se até certo momento é de boa fé, pode passar a ser de má fé, daí em diante. $\mathrm{E}$ não se argumente contra êste ponto de vista, baseado na presunção de boa fé da posse (§ único do art. 490 do Código Civil), pois que ao promitente comprador inadimplente não é dado invocar a crença em uma posse justa sôbre a coisa, objeto do contrato. Qualquer presunção, neste caso, ficaria elidida com o chamamento judicial ou com a atitude inequívoca do inadimplente que deixasse transparecer a oposição do promitente vendedor à sua posse. Tais fatos se não conciliam com crença alguma.

Examinemos, agora, outros efeitos das promessas de compra e venda de imóveis, em casos de rescisões e cancelamento dos contratos respectivos e, bem assim, de falência e falecimento das partes contratantes.

Como é óbvio, o contrato de promessa de venda se extingue por execução voluntária e coativa, por sua resolução e por sua rescisão.

Referiremos, primeiramente, o disposto no Decreto-lei n. ${ }^{\circ}$ $58 \mid 7$, atinente aos imóveis loteados.

As formas de execução voluntária consistem, no simples cumprimenta da obrigaçãd assumida, independentemente de chamamento judicial, ou, quando êste se verifica e o devedor lhe da atendimento, aqueicendo em satisfazer a prestação devida. 
Reza 0 art. 15, do Decreto-lei $n .^{\circ} 58$ aludido:

Os compromitentes têm o direito de, antecipando ou ultimando o pagamento integral do preço, e estando quites com os impostos e taxas, exigir a outorga da escritura de compra e venda".

E o art. 16, do mesmo Decreto-lei, dispõe:

"Recusando-se os compromitentes a passar a escritura definitiva, no caso do art. $5 .^{\circ}$, serão intimados, por despacho judicial e a requerimento do compromissário, a dá-la nos dez dias seguintes à intimação, correndo o prazo em cartório".

Com algumas alterações, esta disposição é reproduzida no art. 346 do Código de Processo Civil, em vigor:

"Recusando-se o compromitente a outorgar escritura definitiva de compra e venda, será intimado, se o requerer o compromissário, a dá-la nos cinco (5) dias seguintes, que correrão em Cartório".

Deduz-se das disposições mencionadas que quando não houver espontaneidade do promitente vendedor no cumprimento da obrigação assumida, ou, mesmo quado êle chegue a expressar sua recusa, não obstante isso, ainda terá oportunidade de reconsiderar sua atitude anterior, cumprindo, voluntà-. riamente, sua obrigação. Só depois de superadas estas fases, é que se dará execução compulsória ou coativa. E esta forma rege-se pelo disposto nos parágrafos do art. 16, do Decreto-lei n. $58 \mid 37$, e pelos parágrafos do art. 346, do Códigó de Processo Civil.

De conformidade com êstes últimos, que estão em pleno vigor, duas hipóteses poderão verificar-se: a) de falta de quaisquer alegações do promitente vendedor, dentro do prazo de cinco (5) dias, e b) de alegação de matéria relevante, no mesmo prazo.

No primeiro caso, dar-se-à a adjudicação compulsória, uma vez que o preço tenha sido integralmente satisfeito. No segundo, haverá o contraditório, com a contestação do promi- 
tente comprador, dentro de cinco (5) dias, e a instauração do período de provas, não excedente de um tríduo (art. 685, do Código de Processo Civil), se as alegações formuladas dependerem de prova, depois do que será proferido o julgamento, concedendo a adjudicação ou denegando-a, conforme o que se apurar na espécie sub judice.

As disposições legais, objeto dêste comentário, tornaramse inaplicáveis, também, aos imóveis não loteados, por fôrça do disposto no art. $10^{\circ}$ da Lei n. ${ }^{\circ} 649 \mid 49$, que deu nova redação ao art. 22, do Decreto-lei n. ${ }^{\circ} 58 \mid 37$. Os requisitos indispensáveis para que se dê a execução compulsória, pela forma específica, são: a ausência de cláusula de arrependimento, no contrato, e a inscrição deste no Registro Imobiliário.

Resolução do contrato. - 0 art. 12 e $\S 1 .^{\circ}$, do citado Decreto-lei $n .^{0} 58$, estabelecem:

"Subentende-se no contrato a condição resolutiva da legitimidade e validade do título de domínio.

Em caso de resolução, além de se devolverem as prestações recebidas, com juros convencionados, ou os da lei, desde a data do pagamento, haverá, quando provada a má fé, direito à indenização de perdas e danos".

As promessas de venda por estas disposições disciplinadas realizam-se no pressuposto de que os títulos dominiais referentes à propriedade prometida são legítimos a válidos. Porisso, está implícita nas mesmas uma condição resolutiva, cuja verificação se dará no momento em que se constatar ou a ilegitimidade ou a invalidade do respectivo título.

Verificada, pois, tal condição, o contrato se resolverá, isto é, tornar-se-á de nenhum efeito, resultando, como dispõe o $\S 1 .^{\circ}$ do art. 12, direito do promitente comprador à devolução, por parte do promitente vendedor, das prestações já pagas, com os juros convencionados, ou em falta de disposição a respeito, com os juros da lei. Ficando, entretanto, provada a má fé do promitente vendedor, que, em tal caso não poderá, de 
nenhum modo, alegar ignorância da ilegitimidade de seu título, o promitente comprador ainda terá direito a uma indenização por perdas e danos.

Afora, porém, a hipótese do mencionado art. 12, com essa condição resolutiva implicita da legitimidade e validade do título de domínio, a promessa de compra e venda poderá resolver-se nos casos e pelas formas em que se resolvem os demais contratos. Assim, é que se lhe aplica o preceito do art. 879 , do Código Civil, 1a. parte, segundo o qual" se a prestação do fato se impossibilitar sem culpa do devedor, resolver-se-à a obrigação". Ficará, de tal arte, sem efeito para ambas as partes o contrato celebrado. Como vemos, é êste um caso comum de resolução dos contratos que encerram obrigações de fazer.

Rescisão do contrato - 0 Decreto-lei n. ${ }^{\circ} 58 \mid 37$ disciplina a rescisão da promessa de compra e venda de imóveis loteados, dispondo em seu art. 14:

"Vencida e não paga a prestação, considera-se o contrato rescindido 30 dias depois de constituido em mora o devedor".

“§ $10^{\circ}$ - Para êste efeito será intimado a requerimento do compromitente, pelo oficial do registro a satisfazer as prestações vencidas e as que se vencerem até a data do pagamento, juros convencionados e custas da intimação".

“§ $20^{\circ}$ - Purgada a mora, convalescerá o compromisso".

"§ $3 .^{\circ}$ - Com a certidão de não haver sido feito pagamento em Cartório, os compromitentes requererão ao oficial do registro o cancelamento da averbação".

Como nos demais contratos, também neste, a rescisão é motivada pelo inadimplemento de uma de suas cláusulas. 0 legislador, aqui, focaliza a obrigação principal do promitente comprador, que é a do pagamento do preço ajustado. Descum- 
prida que ela seja, com a falta do pagamento de uma ou mais prestações, caracterizar-se-á a hipótese de rescisão, uma vez constituido em mora o devedor. Quanto à mora, houve, aliás, derrogação de nosso direito, com o advento do art. $14 \mathrm{e}$ seus parágrafos, por fôrça dos quais os promitentes compradores só serão considerados inadimplentes, se não satisfizerem a obrigação, dentro dos trinta (30) dias que se seguirem à competente e regular notificação ou interpelação.

As disposições do parágrafo $1^{\circ}$ e $2 .^{\circ}$ referidos estão, aliás, em perfeita consonância com o espírito de todo 0 decreto-lei n. $58 \mid 37$, que se propondo a proporcionar segurança e amparo, até então faltantes, aos adquirentes de lotes, que dantes contavam apenas com a seriedade e solvabilidade das emprêzas, vendedoras (3), encerram, também, o papel de os advertir pelo nã́o cumprimento de obrigações e, assim, alertá-los contra o perigo a que se expõem, e lhes concedem oportunidade de cumprirem ditas obrigações, ainda a salvo dos riscos da rescisão.

A convalidação do contrato, pela purgação da mora é, realmente, providência legal incomum, que também se confunde com as altas finalidades, que inspiraram outras disposições do Decreto-lei comentado.

Nos exatos têrmos do $\S 3 .^{\circ}$ do art. 14 , o cancelamento da averbação da promessa de compra e venda só terá lugar com a prova cabal de não ter sido purgada a mora. Se o tiver sido, porém, a promessa se restaura, inteiramente, convalesce, como declara o texto legal, sem que se possa, em outra oportunidade, mesmo de reincidência de atrazo, no pagamento de prestações, alegar tal circunstância para agravar a- situação do promitente comprador. Üma vez que a disposição legal a êste confere uma regalia especialíssima, - porque só se aplica aos promitentes compradores de imóveis loteados, - qualquer sanção só lhe seria aplicável se fôsse prevista em lei.

A rescisão das promessas de compra e venda de imóveis

3) Decreto-lei n. 58|37, considerandos. 
não loteados e a constituição em mora do devedor, nesse contrato, obedecem às disposições comuns aos demais contratos e, de tal modo, não poderão as partes contratantes invocar os preceitos comentados, art. 14 e $\S \S$, do decreto-lei n. ${ }^{\circ} 58$, que, pelos motiyos ốbvios, já ressaltados, não são de aplicação geral e sim especial.

Segundo nos parece, nesses casos, regem-se a constituição em mora pelo disposto nos arts. 953 a 963, do Código Civil, e a rescisão pelas disposições que incidem nos demais contratos do mesmo gênero, e. g., o art. 1092, do Código Civil, e principalmente, seu parágrafo único, os arts. 879 , 2a. parte, e 880 , do mesmo Código.

A êsse respeito, declara Serpa Lopes:

"Em regra, nas promessas de compra e venda, o prazo para a outorga da escritura definitiva se enque "o inadimplemento de obrigação, positiva e líquida, no seu têrmo constitue de pleno direito em mora o devedor" e o de que só “em não havendo prazo assinado, começa ela, desde a interpelação ou protesto" (Cód. Civ. art. 960) (4).

Há escritores (5 e 6) cujo parecer é de que o art. 14, do Decreto-lei n. 58, incidiu nas promessas de venda de imóveis não loteados.

4) Curso de Direito Civil, vol. 3, pág. 218, 1954, Rio de Janeiro.

5) Wilson de S. C. Batalha,-Loteamentos e Condomínio, Tom. I, pág. 389. Nota: Ao fixar os efeitos da Lei n. 649/49, entretanto, o mesmo autor esclarece:

“Os efeitos previstos pela Lei n. 649 para os compromissos de compra e venda de imóveis não loteados, sem a cláusula de arrependimento, devidamente inscritos, são apenas: a) - atribuir ao compromissário comprador direito real oponível a terceiros; b) - conferir-lhe $o$ direito de adjudicação compulsória nos têrmos dos arts. 16 do Decreto-lei n. 58 e 346 do Código de Processo Civil. Por analogia, devem aplicar-se os preceitos dos arts. 17 do Decreto-lei n. 58 e 347 d oCódigo de Processo Civil, relativos à adjudicação compulsória ao compromissário comprador, mediante pedido do compromitente vendedor. Tudo o mais é regulado pelas normas de direito comum" (Loc. cit. págs. 392, 393). Os grifos são nossos.

6) Mario Guimarães, in Estudos de Direito Civil, págs. 12, 16, 1947, São Paulo. 
Preferimos filiar-nos à corrente que esposa a idéia anteriormente exposta e isto principalmente pelo fato de estar de pleno acôrdo com o sistema de nosso Código. O Tribunal de Justiça do Estado de São Paulo, em V. Acórdão de $10^{\circ}$ de setembro de 1953, muito bem decidiu nesse sentido, como se vê desta ementa:

“A nova redação dada ao art. 22 do dec.-lei n. ${ }^{\circ} 58$, de 10 de dezembro de 1937, pela lei n. ${ }^{\circ} 649$, de 11 de março de 1949, tornou claro que aos compromissos de compra e venda de imóveis não loteados só se aplicam os preceitos dos arts. $5 .^{\circ}$ e 16 daquele decretolei e não também o preceito do seu art. 14" (Rev. Forense, vol. 158 , pág. 261).

Tem sido argumento da tese pró-equiparação, para vários efeitos, das promessas de venda de imóveis loteados às referentes a imóveis não loteados, a parte final do art. 22 do Decreto n. 3.079, de 15 de setembro, de 1938. Êste preceito regulamentar estabelece:

"As escrituras de compromisso de compra e venda de imóveis não loteados, cujo preço deva pagar-se a prazo, em uma ou mais prestações, serão averbadas à margem das respectivas transcrições aquisitivas, para os efeitos desta lei, compreendidas nesta disposição as escrituras de promessa de venda de imóveis em geral" (O grifo é nosso).

A disposição transcrita, porém, torna possíveis as averbações de quaisquer promessas de venda, para valerem contra terceiros, não se podendo depreender de seus têrmos que tenha havido uma extensão dos preceitos do Decreto-lei n. $58 \mid 37$ às promessas de venda de imóveis não loteados. Realmente, o Decreto n. ${ }^{0} 3.079 \mid 38$ apenas regula o Decreto-lei n. 58 em apreço, não se lhe podendo reconhecer efeitos mais amplos.

A Lei n. ${ }^{\circ} 649 \mid 49$, por sua vez, especialmente elaborada para disciplinar as promessas de venda de imóveis não loteados, também não tornou extensivos a estas todos os preceitos do mencionado Decreto-lei n. 58. É cristalina a disposição de seu 
art. $1 .^{\circ}$ e nenhuma dúvida padece de que ela extendeu às promessas de venda de imóveis não loteados únicamente os efeitos de valerem erga omnes e de poderem executar-se compulsòriamente, pela forma específica. Isto equivale a dizer que se lhes tornaram aplicáveis as disposições dos arts. $5 .^{\circ}$ e 16 , do Decretolei n. ${ }^{\circ}$ 58, e 346, do vigente Código de Processo Civil.

Nada autoriza, pois, a concluir-se tenha querido o legislador extender outras normas do Decreto-lei n. 58, como a do art. 14, por exemplo, às promessas de venda de imóveis não loteados.

No que tange à constituição em mora do devedor, nas promessas de venda de imóveis não Ioteados, não há como se deixar de fazer a estrita aplicação dos preceitos expressos dos arts. 955 a 963 do Código Civil, que dizem respeito às obrigações em geral. Êstes se acham em pleno vigor. E se houve uma pequena derrogação de seus princípios pelas normás atinentes às promessas de imóveis loteados (art. 14 e $\S \S$, do Dec. lei n. 58|37, esta deve ser entendida restritamente, ou seja, apenas em relação ao objeto determinado - promessas de venda de imóveis loteados. A exceção aberta pela Dec.lei n. ${ }^{0}$ 58|37 e seu Regulamento não justifica generalizações.

Não quer isto dizer que, sob o ponto de vista social, não se possam invocar, nas promessas de venda de imóveis não loteados, razões idênticas às que inspiraram a elaboração da norma do Decreto-lei n. $58 \mid 37$.

O fato porém é que esta constitue a exceção e os interêsses da ordem jurídica estão agazalhados na inflexibilidade do sistema. Os princípios referentes à mora têm um alcance muito grande e jamais poderiam ser sobrepujados pelas normas disciplinadoras de uma espécie de contrato, que o legislador tratou diversamente.

Muitos são os motivos aduzidos em prol da obrigatoriedade da interpelação judicial, para a constituição do devedor em mora, mesmo nos casos em que há prazo assinado às partes, para o cumprimento de suas obrigações. Entre êles, costuma lembrar-se a falta de amparo do promitente comprador que, vítima de sua simplicidade e incúria, chega ao têrmo de sua 
obrigação, sem cumprí-la e ignora que se está expondo à rescisão do contrato celebrado. Por outro lado, a diminução assustadora do poder aquisitivo da moeda e a conseqüente valorização da propriedade imobiliária estimulam, fortemente, os promitentes vendedores menos honestos a deixarem de receber as prestações do preço ajustado, para, rescindindo o contrato não cumprido, realizar negócio mais vantajoso.

A verdade é esta. Todavia êstes fatos, aliás freqüentes, não justificam a completa subversão dos princípios atinentes ao direito das obrigações, que, além de terem inexcedível alcance, foram elaborados com base no pressuposto de que as pessoas obrigadas não têm razões para ignorar o têrmo de suas obrigações e, por outro lado, devem premunir-se contra os que dissimulam tolerância quanto ao retardamento de seus pagamentos.

A astúcia não é empregada sòmente pelos que contratam a promessa de compra e venda de imóveis. De tal modo, se o legislador elaborou normas especiais relativas aos imóveis loteados, não quer isto significar que sua aplicação deva generalizar-se.

Devemos, ainda, referir-nos às promessas comuns de compra e venda.

Nestas, além dos preceitos já considerados para as promessas de venda de imóveis não loteados, referentes à mora, resolução e rescisão, há que se cogitar do exercício do direito de arrependimento e da convenção de arras, de que tratam os arts. 1088 e 1097 do Código Civil. Ditos preceitos se aplicam não só ao contráto de compra e venda, mas também, à respectiva promessa.

0 arrependimento manifestado é, efetivamente, uma forma terminativa do contrato. Os efeitos da resolução, como os da rescisão, contudo, variam, conforme se tratar de arras confirmatórias (art. $1.094 \mathrm{C}$. Civil), de arras penitenciais (art. ciais (art. 1.095 C. Civil) ou de arras penais (art. $1.097 \mathrm{C}$. Civil).

No primeiro caso, é excluido o direito de arrependimento e as arras servem, até, para fortalecer o vínculo estabelecido; 
no segundo, tal direito é reconhecido, expressamente, e, no terceiro, a culpa do contratante que deu as arras é sancionada com a perda das mesmas.

Como vimos, as arras confirmatórias destinam-se a reforçar a obrigação assumida. Assim, uma vez que sejam dadas, é devolvido ao credor o direito de opção entre ficar com as mesmas ou exigir do outro contratante a prestação prometida ou seu equivalente. Além de poder optar pela primeira solução, é forçoso reconhecer-lhe também o direito à diferença entre ditas arras e o total das perdas e danos que lhe forem devidos, se fôr o caso - pois não lhe seria dado acumular arras e perdas e danos, visto não se tratar de pena convencional.

No caso de arras penitenciais, a opção será sempre do arrependido, sendo óbvio que essa faculdade the foi reconhecida expressamente.

No caso das arras penais, o pedido de resolução ou rescisão baseia-se na culpa daquele que impossibilitou a prestação ou execução do contrato e que, porisso, como pena convencional, perderá as arras dadas em benefício do outro.

Efeitos nos casos de falecimento - Nas promessas de compra e venda de imóveis loteados, o falecimento das partes contratantes não resolve o contrato, cuja transmissão se opera aos herdeiros respectivos. A disposição do $\S 2 .^{\circ}$, do art. 12 , do Dec.-lei n. 58|37, é expressa nesse sentido. Outrossim, o mesmo Dec-lei estabelece em seu art. 9. ${ }^{\circ}$ que "o adquirente, por sucessão legítima ou testamentária, da propriedade loteada e inscrita, subroga-se nos direitos e obrigações dos alienantes, autores da herança ou testadores".

Dêsse modo, parece indiscutível, em face do disposto no äecreto-lei citado, que subordina ao estabelecido nos arts. 928 e 1572 do Código Civil, em vigor, que a tranferência, tanto de direitos, como de obrigações, das partes contratantes, se opera aos seus herdeiros, que não poderão eximir-se ao seu cumprimento. Assim, os herdeiros do promitente vendedor estão obrigados a outorgar a escritura definitiva de venda ao promitente comprador e êste a satisfazer o pagamento do preço ajusta- 
do e a receber a escritura, na ocasião própria; da mesma for. ma, os herdeiros do promitente comprador, quando ocorrer a morte dêste, continuarão obrigados à satisfação do preço e recebimento da escritura definitiva, que lhes será outorgada pelo promitente vendedor ou seus herdeiros, se êle também tiver morrido.

Relativamente às promessas de compra e venda de imóveis não loteados, sobram razões para que se conclua de modo idêntico, no caso de falecimento de qualquer das partes contratantes ou de ambas.

A transmissão de direitos e obrigaçães respectivos, em caso de falecimento, dar-se-á de conformidade com os princípios do direito civil disciplinadores da transmissão dos direitos e obrigações em geral.

$\mathrm{O}$ art. 928 do Código Civil dispõe:

"A obrigação, não sendo personalíssima, opera, assim, entre as partes, como entre seus herdeiros".

Por outro lado, o art. 1.572 do mesmo Código reza :

“Aberta a sucessão, o dominio e a posse da herança transmitem-se, desde logo, aos herdeiros legítimos e testamentários".

O insigne Serpa Lopes, em suas considerações sôbre êste aspecto da transmissão de direitos e obrigações, atinentes à promessa de compra e venda, que não se resolve com a morte das partes contratantes, lembra a hipótese que occrrer no caso de comprometer-se uma das partes à alienação de um imóvel, se o mesmo vier a caber em seu quinhão hereditário (dêle, promitente vendedor). Neste caso, pois, excepcionalmente, a morte do promitente será causa de resolução do contrato, visto não se ter verificado, durante sua vida, a condição suspensiva que originaria o direito do promitente comprador, isto é, o pagamento dêsse imóvel em partilha (7).

7) Curso de Direito Civil, vol. 3, pág. 219, 1954, Rio de Janeiro. 
Parece-nos, contudo, que a referida hipótese não configura pròpriamente uma exceção à regra da transmissibilidade de direitos e obrigações e sim um caso de obrigação condicional, que deixa de produzir efeitos por falta de verificação da condição suspensiva a que a mesma se subordina.

Entretanto, o brilhante expositor da matéria refere, em abono da mencionada exceção, um acórdão da 5a. Câmara do Tribunal de Justiça do Distrito Federal, de 12 de agôsto de 1949, em que êle próprio é o Relator do feito (loc. cit.).

Depois de termos mencionado o disposto nos arts. 928 e 1572 do Código Civil, concluimos que seria inexplicável, injustificável mesmo, que a promessa de compra e venda, cuja base é uma obrigação, fizesse exceção às regras em lei consagradas.

É óbvio, pois, que os herdeiros, quer dos promitentes compradores, quer dos promitentes vendedores, da mesma forma que outras pessoas vinculadas pelas diversas obrigações que assumem, subrogam-se nos direitos e obrigações do de cujus.

Em consequência, mesmo após o falecimento, quer do promitente vendedor, quer do promitente comprador, poderá fazer-se a averbação, de que tratam os arts. $5 .^{\circ}$ e 22 do Decretolei n. 58|37, ou a inscrição a que se referem o art. $10^{\circ}$ da Lei n. ${ }^{\circ} 649$, e o art. 178 , letra a), inc. VI do decreto n. $4.857 \mid 39$, para que os titulares dos contratos, cuja transmissão se operou, possam gozar de direitos reais oponíveis a terceiros ou erga omnes.

É que o ato do registro, em nosso sistema, é unilateral, promovido independentemente da intervenção do promitente vendedor. Êste manifesta sua vontade no ato da celebração da promessa.

Não nos parece lógico deixar de aplicar às promessas de compra e venda de imóveis, no que tange ao seu registro, a disposição do art. 233, do Decreto n. 4857 , de 9 de novembro de 1939, assim expressa : 
"O registro será promovido por qualquer interessado, constante dos títulos apresentados, seus sucessores ou representante".

Sendo esta uma norma geral sôbre a realização do registro público, parece-nos que não lhe deve fazer exceção a promessa de compra e venda de imóveis, cujo registro produz efeitos de tanta importância quanto o dos outros contratos.

A propósito do ponto de vista, aqui externado, sôbre o registro das promessas de compra e venda, após a morte das partes contratantes e, bem assim, da completa responsabilidade de seus herdeiros pelos contratos deixados, ousamos lembrar que, em tese de concurso, sustentámos o mesmo em relação ao contrato definitivo de compra e venda. 0 nosso trabalho a êsse respeito se intitulou: "Os herdeiros não se podem eximir ao cumprimento dos contratos do de cujus translativos de direitos reais sôbre imóveis, sob o fudamento de que o adquirente não diligenciou a transcrição de seu título no registro competente" (8)

Na tese aludida, sustentámos que, em face de nosso sistema jurídico, são irrecusáveis estas conclusões:

1) 0 contrato de compra e venda é perfeito e acabado, desde que haja acôrdo sôbre a coisa e o preço (art. 1.126 do Código Civil).

2) O domínio, contudo, só se tranfere, nos contratos sôbre imóveis, na .data da transcrição do respectivo título, no Registro Imobiliário (art. 533 do Código Civil).

3) A referida transcrição, porém, não é fundamento do domínio ou propriedade e sim uma das formas de sua aquisição (art. 530, inc. I, do Código Civil). Reside o fundamento do domínio no ato obrigacional constitutivo ou translativo do direito.

4) A prioridade na aquisição do domínio, pela transcri-

8) Tese de concurso, 1949, Curitiba. 
ção do título aquisitivo, inspira-se, ùnicamente, na necessidade da perfeita organização do Registro e sua continuidade.

5) Dêsse modo, não obstante os rígidos princípios da organização do registro e as sanções que os mesmos encerram, não se pode concluir que a lei ampare atos maliciosos como a alienação de coisa já alienada. 0 que ela reconhece é o direito do adquirente que se antecipa em transcrever, no Registro Imobiliário, seu título aquisitório.

6) Conseqüentemente, não existe disposição expressa ou implícita de lei, que limite o prazo para a transcrição de títulos aquisitivos de imóveis, no Registro competente.

7) Os herdeiros não são terceiros adquirentes e sim sucessores do de cujus; sucedem-no tanto nos direitos como nas obrigações (arts. 928 e 1.572 do Código Civil).

8) Finalmente, se os mesmos herdeiros não cumprirem os contratos translativos de direitos reais, deixados pelo morto, sujeitar-se-ão, como êle próprio se sujeitaria, se vivo fôsse, às conseqüências de seu inadimplemento e não poderão jamais impedir que o adquirente, em qualquer tempo, faça transcrever seu título aquisitivo, no Registro de Imóveis.

Ao defendermos as conclusões apresentadas, contrariamos a opinião de J. M. Carvalho Santos, externada no comentário ao art. 860 do vigente Código Civil onde se lê:

"É uma conseqüência natural do sistema do Código, segundo o qual pela transcrição é que se transfere a propriedade. Logo, enquanto não se transcrever o título de transmissão:

c) se o alienante, antes de transcrito o título, vem a falecer, o imóvel se transfere para seus herdeiros, nos precisos termos do art. 1.572, do Código, ficando insubsietente a alienação anterior, mesmo que venha a ser transcrita" (9)

9) Código Civil Brasileiro Interpretado, vol. X pág. 555, 1944, Rio de Janeiro. 
Contestámos, igualmente, êste excerpto do mesmo autor: "O engano todo está em firmar a conclusão na premissa ampla de que não há prazo fixado para a transcrição ser feita, quando, na verdade o há, qual o que põe termo à propriedade do alienante.

De fato, se o imóvel foi transferido a outrem, depois dessa transferência, a transcrição da alienação anterior é importante.

Se essa é a regra geral, porque excluí-la na hipótese do imóvel passar para o patrimônio dos herdeiros?" (10)

Tornámos claro que o art. 533 do Código Civil, em consonancia com o sistema adotado, teve em mira assegurar a eficácia do registro, para que, através de sua organização, os terceiros ficassem bem informados do verdadeiro estado da propiredade imóvel.

Uma vez que os herdeiros se subrogam nos direitos e obrigações do de cujus, seria ilógico dispensar-lhes tratamento idêntico ao que a lei consigna aos terceiros, pessoas de todo estranhas ao morto e que não lhe sucedem a título universal.

Hoje, a jurisprudência do Egrégio Supremo Tribunal Federal está firmada nesse sentido.

Da exposição feita, deduz-se que os mesmos argumentos poderão invocar-se relativamente às promessas de compra e venda de imóveis, cujos direitos e obrigações também se transmitem, nos casos de falecimento. E, quanto ao seu registro, o que dissemos sôbre a transcrição aplica-se mutatis mutandis, inteiramente, à averbação ou à inscrição, visto serem também atos unilaterais, com a participação do Estado.

Tudo isto decorre do sistema de nossa legislação civil, entendendo-se que a manifestação da vontade das partes se dá por ocasião do contrato e não do registro.

10) Loc. cit., pag. 556 . 
O insigne Prof. Soriano Neto, em seu trabalho intitulado "Publicidade Material do Registro Imobiliário (Efeitos da Transcrição)", esclarece qual a base de nosso sistema registrário, doutrinando:

"Resulta do presente estudo que o Código Civil Brasileiro não acolheu os princípios fundamentais que caracterizam o sistema germânico e a distinguem do francês: o princípio da fôlha do imóvel, que é a base de todo o direito imobiliário formal, e o princípio da publicidade material sob a forma da fé pública, Adota, sòmente, os dois seguintes princípios de direito material: a) o princípio da inscrição: tôda modificação na situação jurídica de um imóvel é subordinada, essencialmente, à uma transcrição ou inscrição no registro de imóveis (efeito constitutivo); “b) o princípio da legitimidade (não na forma do consentimento material do direito alemão - negócio jurídico-real abstrato - mas na do consentimento causal - negócio jurídico - obrigacional - causal), que faz depender a validade da transcrição da existência de pressupostos jurídico-materiais - negócio jurídico válido, de acôrdo com as regras gerais disciplinadoras dos negócios, e faculdade de disposição do alienante, condição essencial de todo negocio real - sem que o limite a exceção constante do $\S 892$ do Código Civil Alemão (v. n. 82). Assim, a transcrição e a inscrição, quer em relação às partes, quer em relação a terceiros de boa ou má fé, não constituem legitimaçãa formal do inscrito e, conseguintemente, não purgam os vícios do título, nem suprem a faculdade de disposição, em uma palavra, não liquidam o domínio ou outro qualquer direito real" (11).

Entre nós, não há o consentimento material do direito ale-

11) Obra cit. págs. 200, 201, Recife, 1940. 
mão - negócio jurídico real abstrato - em virtude do qual ambas as partes fazem declarações para que o regisrtro se efetive. É certo. $O$ art. 925, do Código Civil Alemão, estabelece:

"O acôrdo de vontades do alienante e do adquirente exigido pelo art. 873 para que êle aí tenha transferido a propiredade de um imóvel, realiza-se pela declaração das duas partes presentes ao mesmo tempo diante do bureau fundiário" (12).

0 nosso sistema encerra sòmente o consentimento causal, dado no contrato. Assim, a formalidade do registro, bem ao contrário da do direito alemão, realiza-se independentemente da manifestação do alienante. 0 registro é ato unilateral com participação do Estado.

0 registro de imóveis, levado a efeito, encerra para nós uma presunção juris tantum de domínio (arts. 859 e 860 do Código Civil) e não juris et de jure. Também não acolhemos, em nosso país, o sistema da fé pública dos alemães consagrado no art. 892 do respectivo Código Civil. De tal modo, pode acontecer que o domínio não seja da pessoa em cujo nome figura e, dada a natureza da presunção que o registro encerra, êle desaparecerá, diante da prova de que é de outro o legítimo título que lhe serve de causa.

O valor do ato de alienação sobrepuja, é obvio, ao do registro, pois aquêle é fundamental dêste. Tal assertiva, contudo, não significa a negação dos efeitos do registro em relação a terceiros, bem como da prioridade reconhecida ao que registra seu título, em primeiro lugar (art. 533, Código Civil), e as demais consequências indispensáveis à firmeza do próprio sistema. É necessário, porém, que o ato e seu registro se harmonizem perfeitamente.

No caso, objeto dêste comentário, mesmo que o nosso registro tivesse a eficácia jurídico-formal, do direito alemão, ou encerrasse a pressunção absoluta, do direito : prussiano, - o

12) Code Civil Allemand, trad. de l'Office d Législation étrangere et de Droit international, Paris, 1923. 
que, nem de longe sucede, como vimos, anteriormente, - entendemos que os herdeiros não poderiam, de qualquer modo, impedir a transcrição do título pelo qual o de cujus vendeu bens de raiz, porquanto, nem a êste, se vivo fôsse, assistiria tal faculdade.

Valendo-nos de razões ponderáveis, expostas em trabalho anterior (13), tornamos a afirmar que, por maior importância que tenha a formalidade do registro, no caso, a transcrição, jamais deveremos admitir importe a mesma na subversấo dos mais lídimos princípios do direito obrigacional.

Transparece, claramente, da lição dos mestres e da jurisprudência, que o nosso direito engendrou um sistema de registro imobiliário com feição própria: distanciou-se do sistema franco-italiano, porque só a convenção não basta para a constituição ou transferência de direitos reais; por outro lado, também não consagrou nem os sistemas germânico e suiço e, muito menos, o prussiano, porque a sua eficácia está sempre na dependência de pressupostos jurídico-materiais - negócio jurídico válido e faculdade de disposição.

Esta matéria não comporta maior desenvolvimento, neste trabalho, e a ela apenas nos referimos com brevidade, visto que a promessa de compra e venda também está sujeita ao registro de imóveis.

Concluindo, porém, as considerações expendidas sôbre os efeitos das promessas de venda, nos casos de falecimento, quer do promitente vendedor, quer do promitente comprador, nenhuma dúvida pode restar sôbre a completa eficácia das obrigações assumidas, que se transmitem aos legítimos sucessores dạs partes contratantes. Isso, aliás, é decorrência inelutável do princípio jurídico da transmissibilidade das obrigações.

Dêsse modo, a morte de uma das partes não justifica a resolução do contrato celebrado e, em conseqüência, não exime os sucessores do de cujus, das obrigações que lhes competem.

13) Tese de concurso à Cátedra de D. Civil, da Fac. de Direito da Universidade do Paraná, pág. 47, Curitiba, 1949. 
Efeitos nos casos de falência.

Consoante o disposto no citado art. 12 do Dec.-lei n. 58|37, também não se resolve a promessa bi-lateral de compra e venda, em caso de falência.

Se o falido fôr o promitente vendedor, o contrato será cumprido pelo síndico; se fôr o promitente comprador, será o mesmo contrato vendido, em hasta pública, depois de feita a arrecadação da massa falida (art. $12, \S 20^{\circ}$ do Dec.-Lei n. ${ }^{\circ}$ $58 \mid 37)$.

Em perfeita harmonia com as disposições do citado Decreto-lei e seu Regulamento, está a Lei de Falência (Decreto-lei n. ${ }^{\circ}$ 7.661, de 21 de junho de 1945). Seu art. 43 dispõe:

"Os contratos bilaterais não se resolvem pela falência e podem ser executados pelo síndico se achar de conveniência para a massa".

Além disso, seu art. 44 e inc. VI estabelecem:

"Nas relações contratuais abaixo mencionadas, prevalecerão as seguinte regras:

VI - Na promessa de compra e venda de imóveis, aplicar-se-à a legislação respectiva".

Com a ressalva constante da mencionada disposição legal, não padece qualquer dúvida quanto à completa iutcidência das disposições do aludido Decreto-lei n. 58|37, quando se tratar de promessas de compra e venda de imóveis loteados.

Às outras modalidades de promessas de venda de imóveis aplicam-se ou as disposições da Lei n. ${ }^{0} 649 \mid 49$ ou as do Código Civil Brasileiro, ou ambas, se fôr o caso, combinadas com o mencionado art. 43 da Lei de Falências, e, de igual modo, a falência não as resolve. 